\title{
Sesquiterpenoids from the Formosan Soft Coral Lemnalia flava
}

\author{
Jui-Hsin Su, ${ }^{a, b, c}$ Yi Lu, ${ }^{a}$ Wen-Yu Hung,${ }^{a}$ Chiung-Yao Huang, ${ }^{a}$ Michael Y. Chiang, ${ }^{d}$ \\ Ping-Jyun SunG, ${ }^{b, c}$ Yao-Haur Kuo, ${ }^{e}$ and Jyh-Horng SHEU ${ }^{*}, a, f$ \\ ${ }^{a}$ Department of Marine Biotechnology and Resources, National Sun Yat-sen University; ${ }^{d}$ Department of Chemistry, \\ National Sun Yat-sen University; ${ }^{f}$ Asia-Pacific Ocean Research Center, National Sun Yat-sen University; Kaohsiung 804, \\ Taiwan: ${ }^{b}$ National Museum of Marine Biology \& Aquarium; Checheng, Pingtung 944, Taiwan: ${ }^{c}$ Graduate Institute of \\ Marine Biotechnology, National Dong Hwa University; Pingtung 944, Taiwan: and ${ }^{e}$ National Research Institute of \\ Chinese Medicine; Taipei 112, Taiwan.
}

Received January 14, 2011; accepted March 15, 2011; published online March 24, 2011

Four new nardosinane-type sesquiterpenoids, flavalins E-H (1-4) and two new nornardosinane-type norsesquiterpenoids, flavalins I (5) and $J(6)$, along with five known compounds (7-11) have been isolated from a Formosan soft coral Lemnalia flava. The structures of these compounds were elucidated on the basis of their spectroscopic data. Moreover, the absolute configuration of 10 was further determined by Mosher's method.

Key words sesquiterpenoid; soft coral; Lemnalia flava

Our chemical studies on the Formosan soft corals have resulted in the discovery of series of bioactive natural products, including sesquiterpnoids, ${ }^{1-3)}$ diterpenoids, ${ }^{4-8)}$ steroids $^{9-11)}$ and others. ${ }^{12)}$ Previous chemical investigations on soft corals of the genus Lemnalia have led to the isolation and identification of varieties of sesquiterpenoids. Some of these were found to possess several kinds of biological activities such as cytotoxic, ${ }^{13,14)}$ antimicrobial, ${ }^{15)}$ and anti-inflammatory properties. ${ }^{16)}$ In a previous paper, we reported the discovery of four new sesquiterpenoids with nardosinane-type skeleton from a Formosan soft coral Lemnalia flava. ${ }^{17)}$ During our continuing studies on the chemical constituents from the same collection of $L$. flava, we further yielded four new nardosinane-type sesquiterpenoids, flavalins $\mathrm{E}-\mathrm{H}(\mathbf{1}-\mathbf{4})$, and two new nornardosinane-type norsesquiterpenoids, flavalins I (5) and J (6), along with five known compounds, 2-oxolemnacarnol (7), ${ }^{18)}$ lemnacarnol (8), ${ }^{18,19)}$ armatin $\mathrm{F}(\mathbf{9}),{ }^{20)}(2 R)-2$ hydroxylemnal-1(10)-en-12-one $(\mathbf{1 0})^{21)}$ and laevinol B (11) ${ }^{14)}$ The structures of the new compounds were established by extensive spectroscopic analysis, including careful examination of 2D-NMR correlations, and the absolute configuration of $\mathbf{1 0}$ was further determined using Mosher's method. ${ }^{22)}$ The cytotoxicity of compounds $\mathbf{1}-\mathbf{1 1}$ against several cancer cell lines, including human breast carcinoma (MCF-7), human colon carcinoma (WiDr), human laryngeal carcinoma (HEp 2), human medulloblastoma (Daoy), T-cell acute lymphoblastic leukemia (CCRF-CEM), colon adenocarcinoma (DLD-1), human promyelocytic leukemia (HL60 ) and murine leukemia (P388D1) cell lines, was studied.

The high resolution (HR) electrospray ionization-mass spectrum (ESI-MS) $\left(\mathrm{m} / z\right.$ 287.1621 $\left.[\mathrm{M}+\mathrm{Na}]^{+}\right)$of flavalin E (1) established the molecular formula $\mathrm{C}_{16} \mathrm{H}_{24} \mathrm{O}_{3}$, appropriate for five of unsaturation, and the IR spectrum revealed the presence of carbonyl $\left(1710 \mathrm{~cm}^{-1}\right)$ group. The ${ }^{13} \mathrm{C}$-NMR and distortionless enhancement by polarization transfer (DEPT) (Table 1) spectroscopic data showed signals of four methyls (including one methoxyl), four $s p^{3}$ methylenes (including one oxymethylene), three $s p^{3}$ methines, one $s p^{2}$ methines, two $s p^{3}$ (including one dioxymethine) and two $s p^{2}$ quaternary carbons (including one carbonyl). The ${ }^{13} \mathrm{C}$ data of $\mathbf{1}$, measured in $\mathrm{CDCl}_{3}$ (Table 1), showed a $\alpha, \beta$-unsaturated keto group resonating at $\delta$ 198.4. The ${ }^{1} \mathrm{H}$ data (Table 2) of $\mathbf{1}$

showed signals of two secondary methyls $(\delta 0.98$, d, $J=6.0 \mathrm{~Hz} ; \delta 1.07, \mathrm{~d}, J=6.0 \mathrm{~Hz})$ and a tertiary methyl $(\delta 1.23$, s). The above data accounted for one of the five degrees of unsaturation, indicating a tricyclic structure of $\mathbf{1}$. In the ${ }^{1} \mathrm{H}-{ }^{1} \mathrm{H}$ correlation spectroscopy (COSY) spectrum, it was possible to identify three different structural units, which were assembled with the assistance of an heteronuclear multiple bond correlation (HMBC) experiment (Fig. 1). Key HMBC correlations of $\mathrm{H}_{3}-14$ to $\mathrm{C}-3, \mathrm{C}-4$ and $\mathrm{C}-5 ; \mathrm{H}_{3}-15$ to

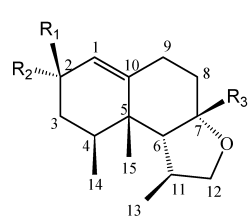
$1: \mathrm{R}_{1}, \mathrm{R}_{2}=\mathrm{O}, \mathrm{R}_{3}=\mathrm{OMe}$ $2: \mathrm{R}_{1}=\mathrm{OH}, \mathrm{R}_{2}=\mathrm{H}, \mathrm{R}_{3}=\mathrm{OH}$
$7: \mathrm{R}_{1}, \mathrm{R}_{2}=\mathrm{O}, \mathrm{R}_{3}=\mathrm{OH}$ $7: \mathrm{R}_{1}, \mathrm{R}_{2}=\mathrm{O}, \mathrm{R}_{3}=\mathrm{OH}$
$8: \mathrm{R}_{1}=\mathrm{H}, \mathrm{R}_{2}=\mathrm{OH}, \mathrm{R}_{3}=\mathrm{OH}$

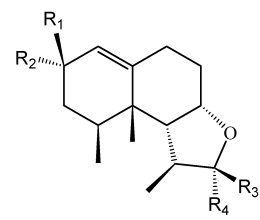

$3: \mathrm{R}_{1}, \mathrm{R}_{2}=\mathrm{O}, \mathrm{R}_{3}=\mathrm{H}, \mathrm{R}_{4}=\mathrm{OMe}$ $4: \mathrm{R}_{1}=\mathrm{H}, \mathrm{R}_{2}=\mathrm{OAc}, \mathrm{R}_{3}=\mathrm{OMe}, \mathrm{R}_{4}=\mathrm{H}$ $9: \mathrm{R}_{1}, \mathrm{R}_{2}=\mathrm{O}, \mathrm{R}_{3}=\mathrm{OMe}, \mathrm{R}_{4}=$ $10: \mathrm{R}_{1}=\mathrm{OH}, \mathrm{R}_{2}=\mathrm{H}, \mathrm{R}_{3}, \mathrm{R}_{4}=\mathrm{O}$

Chart 1

Table 1. ${ }^{13} \mathrm{C}-\mathrm{NMR}$ Spectral Data for Compounds $\mathbf{1}-\mathbf{6}$

\begin{tabular}{|c|c|c|c|c|c|c|}
\hline & $\mathbf{1}^{a)}$ & $2^{a)}$ & $\mathbf{3}^{a)}$ & $4^{b)}$ & $5^{a)}$ & $6^{a)}$ \\
\hline 1 & $126.5, \mathrm{CH}^{c)}$ & $127.3, \mathrm{CH}$ & $126.8, \mathrm{CH}$ & $119.1, \mathrm{CH}$ & 125.6, CH & $128.0, \mathrm{CH}$ \\
\hline 2 & $198.4, \mathrm{qC}$ & 67.6, $\mathrm{CH}$ & $198.5, \mathrm{qC}$ & $67.2, \mathrm{CH}$ & 198.0, qC & 199.0, qC \\
\hline 3 & $41.7, \mathrm{CH}_{2}$ & $36.9, \mathrm{CH}_{2}$ & $41.8, \mathrm{CH}_{2}$ & $34.8, \mathrm{CH}_{2}$ & $41.1, \mathrm{CH}_{2}$ & $41.3, \mathrm{CH}_{2}$ \\
\hline 4 & $35.7, \mathrm{CH}$ & $33.7, \mathrm{CH}$ & $35.3, \mathrm{CH}$ & $26.8, \mathrm{CH}$ & $35.1, \mathrm{CH}$ & $35.3, \mathrm{CH}$ \\
\hline 5 & $41.9, \mathrm{qC}$ & $40.6, \mathrm{qC}$ & 41.6, qC & $40.8, \mathrm{qC}$ & $42.6, \mathrm{qC}$ & $41.9, \mathrm{qC}$ \\
\hline 6 & $58.4, \mathrm{CH}$ & $59.1, \mathrm{CH}$ & $53.2, \mathrm{CH}$ & $54.9, \mathrm{CH}$ & $60.3, \mathrm{CH}$ & $60.4, \mathrm{CH}$ \\
\hline 7 & $110.5, \mathrm{qC}$ & $107.3, \mathrm{qC}$ & 77.6, $\mathrm{CH}$ & $78.5, \mathrm{CH}$ & $68.5, \mathrm{CH}$ & $65.2, \mathrm{CH}$ \\
\hline 8 & $28.6, \mathrm{CH}_{2}$ & $33.4, \mathrm{CH}_{2}$ & $28.3, \mathrm{CH}_{2}$ & $31.7, \mathrm{CH}_{2}$ & $29.0, \mathrm{CH}_{2}$ & $35.5, \mathrm{CH}_{2}$ \\
\hline 9 & $28.0, \mathrm{CH}_{2}$ & 27.2, $\mathrm{CH}_{2}$ & $29.2, \mathrm{CH}_{2}$ & $27.8, \mathrm{CH}_{2}$ & $30.4, \mathrm{CH}_{2}$ & 73.6, CH \\
\hline 10 & 169.6, qC & $142.2, \mathrm{qC}$ & $168.3, \mathrm{qC}$ & 151.6, qC & $166.5, \mathrm{qC}$ & $165.5, \mathrm{qC}$ \\
\hline 11 & $38.7, \mathrm{CH}$ & $36.7, \mathrm{CH}$ & $42.4, \mathrm{CH}$ & $40.6, \mathrm{CH}$ & 211.1, qC & $211.3, \mathrm{qC}$ \\
\hline 12 & $72.6, \mathrm{CH}_{2}$ & 72.1, $\mathrm{CH}_{2}$ & $114.0, \mathrm{CH}$ & $108.8, \mathrm{CH}$ & $35.6, \mathrm{CH}_{3}$ & $35.6, \mathrm{CH}_{3}$ \\
\hline 13 & $17.1, \mathrm{CH}_{3}$ & $19.0, \mathrm{CH}_{3}$ & $19.7, \mathrm{CH}_{3}$ & $13.5, \mathrm{CH}_{3}$ & $15.2, \mathrm{CH}_{3}$ & $14.9, \mathrm{CH}_{3}$ \\
\hline 14 & $15.9, \mathrm{CH}_{3}$ & $16.2, \mathrm{CH}_{3}$ & $15.7, \mathrm{CH}_{3}$ & $18.0, \mathrm{CH}_{3}$ & $17.8, \mathrm{CH}_{3}$ & $19.1, \mathrm{CH}_{3}$ \\
\hline 15 & $19.1, \mathrm{CH}_{3}$ & $21.2, \mathrm{CH}_{3}$ & $19.4, \mathrm{CH}_{3}$ & $19.2, \mathrm{CH}_{3}$ & & \\
\hline 2-OAc & & & & $21.5, \mathrm{CH}_{3}$ & & \\
\hline & & & & $170.9, \mathrm{qC}$ & & \\
\hline 7-OMe & $48.9, \mathrm{CH}_{3}$ & & & & & \\
\hline $12-\mathrm{OMe}$ & & & $55.8, \mathrm{CH}_{3}$ & $54.8, \mathrm{CH}_{3}$ & & \\
\hline
\end{tabular}

a) Spectrum recorded at $125 \mathrm{MHz}$ in $\mathrm{CDCl}_{3}$. b) $100 \mathrm{MHz}$ in $\mathrm{CDCl}_{3}$. c) Attached protons deduced by DEPT experiment. 
Table 2. ${ }^{1}$ H-NMR Spectral Data for Compounds $\mathbf{1}-\mathbf{6}$

\begin{tabular}{|c|c|c|c|c|c|c|}
\hline & $\mathbf{1}^{a)}$ & $2^{a)}$ & $\mathbf{3}^{a)}$ & $4^{b)}$ & $5^{a)}$ & $6^{a)}$ \\
\hline 1 & $5.92 \mathrm{~s}$ & $5.51 \mathrm{~s}$ & $5.90 \mathrm{brs}$ & $5.42 \mathrm{~d}(4.0)$ & $5.87 \mathrm{~d}(1.5)$ & $5.95 \mathrm{~s}$ \\
\hline 2 & & $4.24 \mathrm{dd}(8.0,6.5)$ & & $5.06 \mathrm{dd}(4.8,4.8)$ & & \\
\hline \multirow[t]{2}{*}{3} & $2.28 \mathrm{~m}$ & $1.80 \mathrm{~m}$ & $2.26 \mathrm{~m}$ & $1.59 \mathrm{~m}$ & $2.19 \mathrm{~m}$ & $2.27 \mathrm{~m}$ \\
\hline & $2.34 \mathrm{~m}$ & $\begin{array}{l}1.43 \mathrm{ddd}(12.0,12.0 \\
6.5)\end{array}$ & $2.24 \mathrm{dt}(17.0,6.0)$ & $1.78 \operatorname{td}(15.2,4.8)$ & & $2.24 \mathrm{~m}$ \\
\hline 4 & $2.33 \mathrm{~m}$ & $1.84 \mathrm{~m}$ & $2.28 \mathrm{~m}$ & $2.00 \mathrm{~m}$ & $2.19 \mathrm{~m}$ & $2.23 \mathrm{~m}$ \\
\hline 6 & $1.99 \mathrm{~d}(10.0)^{c)}$ & $1.78 \mathrm{~d}(10.0)$ & $2.23 \mathrm{dd}(10.0,7.5)$ & $1.97 \mathrm{~m}$ & $3.52 \mathrm{~d}(5.0)$ & $3.53 \mathrm{~d}(5.5)$ \\
\hline 7 & & & $4.49 \mathrm{dd}(13.5,7.0)$ & $\begin{array}{l}3.73 \text { ddd }(11.2,9.6, \\
7.2)\end{array}$ & $4.37 \mathrm{dt}(12.0,5.0)$ & $4.74 \mathrm{dt}(12.0,5.0)$ \\
\hline \multirow[t]{2}{*}{8} & $\begin{array}{l}2.07 \text { ddd }(13.5,5.0 \text {, } \\
3.0)\end{array}$ & $1.95 \mathrm{~m}$ & $\begin{array}{l}2.01 \operatorname{tdd}(13.5,7.0 \\
\quad 6.0)\end{array}$ & $2.13 \mathrm{~m}$ & $1.99 \mathrm{qd}(12.0,6.0)$ & $2.14 \mathrm{dd}(12.0,4.5)$ \\
\hline & $1.95 \operatorname{td}(13.5,6.0)$ & $1.78 \mathrm{~m}$ & $1.91 \mathrm{~m}$ & $1.57 \mathrm{~m}$ & $1.87 \mathrm{~m}$ & $2.05 \mathrm{dd}(13.5,5.0)$ \\
\hline \multirow[t]{2}{*}{9} & $2.57 \mathrm{~m}$ & $2.45 \mathrm{~m}$ & $2.66 \mathrm{dt}(17.0,6.0)$ & $2.54 \mathrm{q}(10.4)$ & $2.57 \mathrm{dd}(6.0,2.5)$ & $4.59 \mathrm{dd}(4.5,2.0)$ \\
\hline & $2.54 \mathrm{~m}$ & $2.22 \mathrm{~m}$ & $\begin{array}{l}2.43 \text { dddd }(17.0,9.5 \\
5.5,1.5)\end{array}$ & $1.99 \mathrm{~m}$ & $2.54 \operatorname{td}(6.0,2.0)$ & \\
\hline 11 & $\begin{array}{l}1.84 \mathrm{ddq}(11.0,8.0 \\
6.0)\end{array}$ & $1.93 \mathrm{~m}$ & $1.92 \mathrm{~m}$ & $2.19 \mathrm{~m}$ & & \\
\hline \multirow[t]{2}{*}{12} & $3.90 \mathrm{dd}(8.0,8.0)$ & $3.88 \mathrm{t}(8.5)$ & $4.57 \mathrm{~d}(3.5)$ & $4.74 \mathrm{~d}(4.8)$ & $2.27 \mathrm{~s}$ & $2.27 \mathrm{~s}$ \\
\hline & $3.41 \mathrm{dd}(11.0,8.0)$ & $3.48 \mathrm{t}(9.0)$ & & & & \\
\hline 13 & $1.07 \mathrm{~d}(6.0)$ & $1.10 \mathrm{~d}(6.5)$ & $1.21 \mathrm{~d}(6.5)$ & $1.17 \mathrm{~d}(6.8)$ & $1.01 \mathrm{~d}(6.0)$ & $1.00 \mathrm{~d}(6.5)$ \\
\hline 14 & $0.98 \mathrm{~d}(6.0)$ & $0.90 \mathrm{~d}(6.5)$ & $0.99 \mathrm{~d}(5.5)$ & $1.01 \mathrm{~d}(6.8)$ & $1.15 \mathrm{~s}$ & $1.37 \mathrm{~s}$ \\
\hline 15 & $1.23 \mathrm{~s}$ & $1.18 \mathrm{~s}$ & $1.15 \mathrm{~s}$ & $1.02 \mathrm{~s}$ & & \\
\hline 2-OAc & & & & $2.03 \mathrm{~s}$ & & \\
\hline 7-OMe & $3.32 \mathrm{~s}$ & & & & & \\
\hline 12-OMe & & & $3.36 \mathrm{~s}$ & $3.34 \mathrm{~s}$ & & \\
\hline
\end{tabular}

a) Spectrum recorded at $500 \mathrm{MHz}$ in $\mathrm{CDCl}_{3}$. b) $400 \mathrm{MHz}$ in $\mathrm{CDCl}_{3}$. c) $J$ values in $\mathrm{Hz}$ in parentheses.

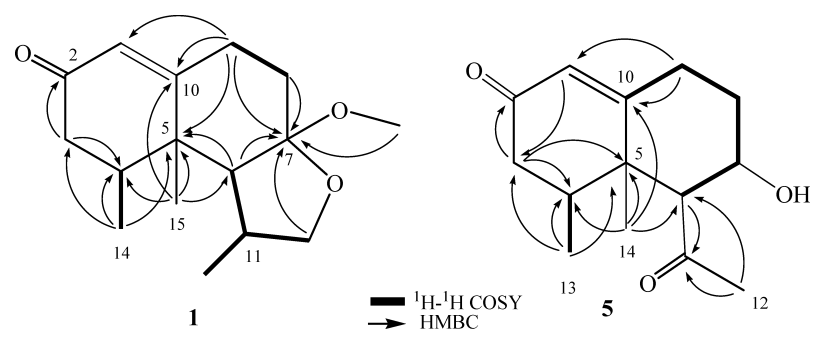

Fig. 1. Key ${ }^{1} \mathrm{H}-{ }^{1} \mathrm{H}$ COSY and $\mathrm{HMBC}$ Correlations for $\mathbf{1}$ and $\mathbf{5}$

C-4, C-5, C-6 and C-10; $\mathrm{H}_{2}-12$ to C-7, $\mathrm{H}_{2}-3$ to C-2 and C-4; $\mathrm{H}-6$ to $\mathrm{C}-5$ and $\mathrm{C}-7 ; \mathrm{H}_{2}-8$ and $\mathrm{C}-7$; and $\mathrm{H}_{2}-9$ to $\mathrm{C}-1, \mathrm{C}-5$, and $\mathrm{C}-10$, allow the establishment of the carbon skeleton. On the basis of the above analysis, the planar structure of $\mathbf{1}$ was established unambiguously. Furthermore, the relative structure of $\mathbf{1}$ was elucidated by the analysis of nuclear Overhauser effect (NOE) correlations, as shown in Fig. 2. It was found that $\mathrm{H}_{3}-15(\delta 1.23, \mathrm{~s})$ showed NOE interactions with H-6 ( $\delta 1.99$, d, $J=10.0 \mathrm{~Hz}), \mathrm{H}_{3}-14(\delta 0.98, \mathrm{~d}, J=6.0 \mathrm{~Hz})$ and a proton at C-8 $(\delta 2.07$, ddd, $J=13.5,5.0,3.0 \mathrm{~Hz})$; therefore, assuming a $\beta$-orientation of $\mathrm{H}_{3}-15, \mathrm{H}_{3}-14$ and $\mathrm{H}-6$ should also be positioned on the $\beta$-face. NOE correlations of the methoxyl and both protons at $\mathrm{C}-8$ were observed, indicating a $\beta$-orientation of methoxyl at C-7. Moreover, the structure was also confirmed by comparison of the similar ${ }^{1} \mathrm{H}$ - and ${ }^{13} \mathrm{C}$-NMR data of 1 with those of known compound $7,{ }^{18)}$ with the difference that $\mathbf{1}$ contains one methoxyl relative to the hydroxyl of $\mathbf{7}$. On the basis of the above findings and other detailed NOE correlations (Fig. 2), the relative structure of $\mathbf{1}$ was determined.

Flavalin F (2) was obtained as a white solid. A molecular formula $\mathrm{C}_{15} \mathrm{H}_{24} \mathrm{O}_{3}$ for $\mathbf{2}$ was suggested by ESI-MS, ${ }^{13} \mathrm{C}$ - and ${ }^{1} \mathrm{H}-\mathrm{NMR}$ spectral data (Tables 1,2), and the HR-ESI-MS of
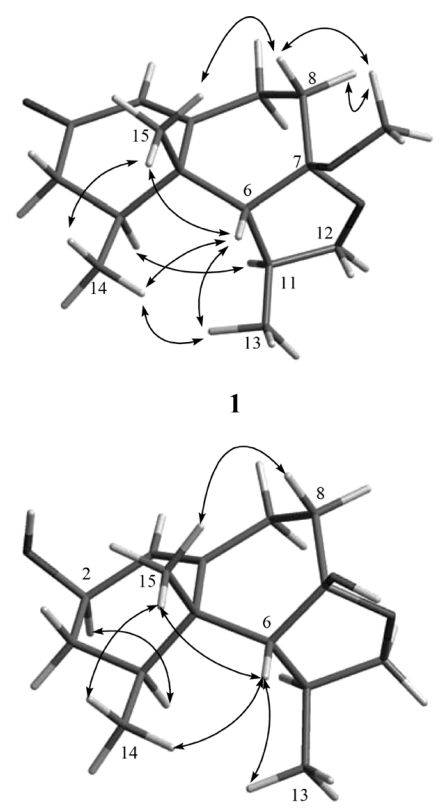

2

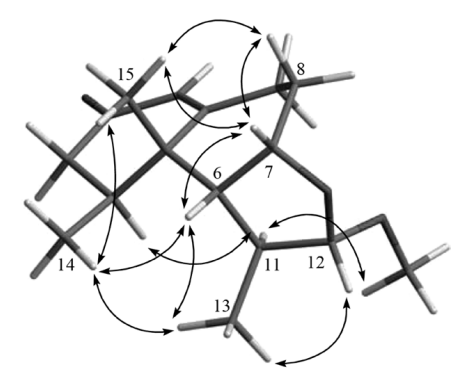

3

Fig. 2. Selective NOESY Correlations of $\mathbf{1}-\mathbf{3}$ 
the acetyl derivative of $\mathbf{2}$ (see Experimental). The IR spectrum of $\mathbf{2}$ showed the absorption of hydroxy group $\left(3356 \mathrm{~cm}^{-1}\right)$. By comparison of the NMR spectroscopic data (Tables 1,2 ) of $\mathbf{2}$ and $\mathbf{8},^{18,19)}$ compound $\mathbf{2}$ was shown to possess the same planar structure as that of $\mathbf{8}$. Furthermore, assuming the $\beta$-orientation of $\mathrm{H}_{3}-15$, the key $\mathrm{NOE}$ correlations between H-2 $(\delta 4.24$, dd, $J=8.0,6.5 \mathrm{~Hz})$ and H-4 $(\delta 1.84$, $\mathrm{m})$, and $\mathrm{H}_{3}-14(\delta 0.90, \mathrm{~d}, J=6.5 \mathrm{~Hz})$ and $\mathrm{H}_{3}-15(\delta 1.18, \mathrm{~s})$ suggested the $\beta$-orientation of hydroxy group at $\mathrm{C}-2$. From the above observations and further analysis of other NOE interactions (Fig. 2), $\mathbf{2}$ was revealed to be the C-2 epimer of $\mathbf{8}$. Thus, the structure of $\mathbf{2}$ was established.

The HR-ESI-MS flavalin G (3) determined the molecular formula $\mathrm{C}_{16} \mathrm{H}_{24} \mathrm{O}_{3}\left(\mathrm{~m} / z\right.$ 287.1622 $\left.[\mathrm{M}+\mathrm{Na}]^{+}\right)$. By 2D-NMR spectroscopic data, including ${ }^{1} \mathrm{H}-{ }^{1} \mathrm{H}$ COSY, heteronuclear multiple quantum correlation (HMQC), and HMBC, compound 3 was shown to possess the same molecular framework as that of 9. ${ }^{20)}$ Furthermore, it was found that the NMR data of $\mathbf{3}$ were very similar to those of $\mathbf{9}$, suggesting that $\mathbf{3}$ might be an isomer of 9 . By nuclear Overhauser effect spectroscopy (NOESY) (Fig. 2), it was found that $\mathrm{H}_{3}-15(\delta 1.15$, s) showed NOE interactions with H-7 $(\delta 4.49$, dd, $J=13.5$, $7.0 \mathrm{~Hz})$ and $\mathrm{H}_{3}-14(\delta 0.99, \mathrm{~d}, J=5.5 \mathrm{~Hz})$; therefore, assuming the $\beta$-orientation of $\mathrm{H}_{3}-15, \mathrm{H}-7$ and $\mathrm{H}_{3}-14$ should also be positioned on the $\beta$ face. NOE correlations of $\mathrm{H}_{3}-13$ with $\mathrm{H}-6$, $\mathrm{H}-12$ and $\mathrm{H}_{3}-14$ exhibited the $\beta$-orientation of $\mathrm{C}-13$ at $\mathrm{C}-11$. On the other hand, $\mathrm{H}-11$ showed NOE correlations with $\mathrm{H}-4$ and methoxyl, indicating $\alpha$-orientation of methoxyl at C-12. On the basis of the above findings, 3 was revealed to be the C-12 epimer of 9.

The HR-ESI-MS of flavalin $\mathrm{H}$ (4) showed that it possesses the molecular formula $\mathrm{C}_{18} \mathrm{H}_{28} \mathrm{O}_{4}\left(\mathrm{~m} / z\right.$ 331.1881 $\left.[\mathrm{M}+\mathrm{Na}]^{+}\right)$. The IR spectrum of $\mathbf{4}$ showed the absorption of carbonyl group $\left(1717 \mathrm{~cm}^{-1}\right)$. Comparison of the ${ }^{1} \mathrm{H}$ - and ${ }^{13} \mathrm{C}-\mathrm{NMR}$ spectroscopic data (Tables 1,2 ) of compounds $\mathbf{4}$ and $\mathbf{9}^{20)}$ showed that the structure of $\mathbf{4}$ should be very similar to that of 9, with the exception of signals assigned to $\mathrm{C}-2$, where a keto group in 9 was replaced by one acetoxymethine $\left(\delta_{\mathrm{H}}\right.$ $2.03,3 \mathrm{H}, \mathrm{s}, \delta_{\mathrm{C}} 170.9$ and $21.5 ; \delta_{\mathrm{H}} 5.06$, dd, $J=4.8,4.8 \mathrm{~Hz}$, $\left.\delta_{\mathrm{C}} 67.2\right)$ in 4 . Furthermore, the key NOE correlation between $\mathrm{H}-11(\delta 2.19, \mathrm{~m})$ and both $\mathrm{H}-4$ and $\mathrm{H}-12(\delta$ 4.74, $\mathrm{d}$, $J=4.8 \mathrm{~Hz}$ ) showed the $\beta$-orientation of $\mathrm{H}_{3}-13$ and methoxyl at $\mathrm{C}-12$, assuming the $\alpha$-orientation of $\mathrm{H}-4$. H-2 exhibited $\mathrm{NOE}$ correlations with both protons of $\mathrm{H}_{2}-3$, but not $\mathrm{H}-4$, reflecting the $\alpha$-orientation of the acetoxy group at C-2. From the above observations and further analysis of other NOE interactions (Fig. 3), the structure of $\mathbf{4}$ was established.

The HR-ESI-MS of flavalin I (5) revealed that it possesses the molecular formula $\mathrm{C}_{14} \mathrm{H}_{20} \mathrm{O}_{3}\left(\mathrm{~m} / z 259.1310[\mathrm{M}+\mathrm{Na}]^{+}\right)$.

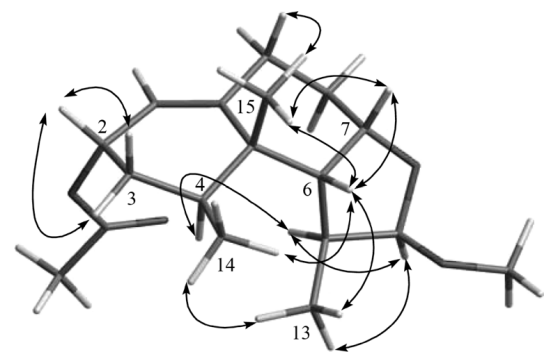

Fig. 3. Selective NOESY Correlations of $\mathbf{4}$
The IR spectrum of $\mathbf{5}$ showed the absorption of carbonyl groups $\left(1716,1669 \mathrm{~cm}^{-1}\right)$ and hydroxy groups $\left(3333 \mathrm{~cm}^{-1}\right)$. Comparison of the ${ }^{1} \mathrm{H}$ - and ${ }^{13} \mathrm{C}$-NMR spectroscopic data of $\mathbf{5}$ (Tables 1,2) with those of $\mathbf{1 1}^{13)}$ showed that the structure of 5 should be very close to that of 11, with the exception of signals assigned to $\mathrm{C}$-2, where a hydroxymethine in $\mathbf{1 1}$ was replaced by a keto group $\left(\delta_{\mathrm{C}} 198.0\right)$ in $\mathbf{5}$. This was further supported by the planar structure established by 2D-NMR analysis of 5 (Fig. 1). Furthermore, $\mathrm{H}_{3}-14\left(\delta_{\mathrm{H}} 1.15, \mathrm{~s}\right)$ exhibited NOE correlations with $\mathrm{H}_{3}-13\left(\delta_{\mathrm{H}} 1.01, \mathrm{~d}, J=6.0 \mathrm{~Hz}\right), \mathrm{H}-$ $6\left(\delta_{\mathrm{H}} 3.52, \mathrm{~d}, J=5.0 \mathrm{~Hz}\right)$ and $\mathrm{H}-7\left(\delta_{\mathrm{H}} 4.37, \mathrm{dt}, J=12.0\right.$, $5.0 \mathrm{~Hz}$ ) showed the $\alpha$-orientation of both acetyl group at C-6 and hydroxy group at C-7. Thus, the structure of $\mathbf{5}$ was established.

A molecular formula for $\mathrm{C}_{14} \mathrm{H}_{20} \mathrm{O}_{4}$ for flavalin $\mathrm{J}$ (6) was suggested by HR-ESI-MS. The IR spectrum of $\mathbf{6}$ showed the absorptions of carbonyl groups $\left(1719,1657 \mathrm{~cm}^{-1}\right)$ and hydroxy group $\left(3393 \mathrm{~cm}^{-1}\right)$. The NMR spectroscopic data of 6 were found to be very similar to those of 5 (Tables 1,2 ) with the exception of signals assigned to $\mathrm{C}-9$, where a methylene in 5 was replaced by an oxymethine $\left(\delta_{\mathrm{H}} 4.59\right.$, dd, $J=4.5$, $2.0 \mathrm{~Hz} ; \delta_{\mathrm{C}}$ 73.6) in 6. The NOESY spectrum of 6 (Fig. 4) showed correlations of H-9 with H-1 $(\delta 5.95, \mathrm{~s})$ and both protons at C-8 $\left(\delta_{\mathrm{H}} 2.14, \mathrm{~d}, J=12.0,4.5 \mathrm{~Hz}\right.$ and 2.05 , dd, $J=13.5,5.0 \mathrm{~Hz}$ ), indicating the $\beta$-orientation of the C-9 hydroxy group. Further analysis of NOE correlations revealed that 6 possessed the same configurations at C-4, C-5, C-6, and $\mathrm{C}-7$, as those in compound $\mathbf{5}$. On the basis of the above findings, the structure of $\mathbf{6}$ was established.

The absolute configuration of $\mathbf{1 0}$ was also determined by the use of Mosher's method. ${ }^{22)}$ The $(S)$ - and $(R)$ - $\alpha$-methoxy$\alpha$-trifluoromethylphenylacetic acid (MTPA) esters of $\mathbf{1 0}$ (10a, b, respectively) were prepared using the corresponding $R$-(-)- and $S$ - $(+)-\alpha$-methoxy- $\alpha$-(trifluoromethyl)phenyl-

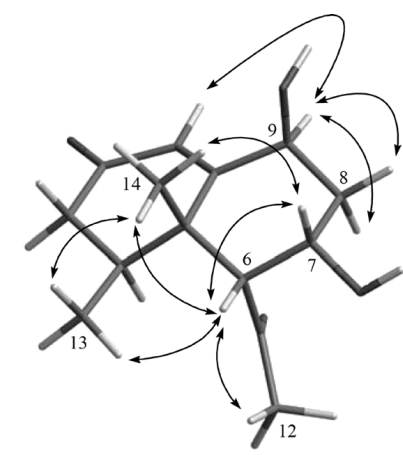

Fig. 4. Selective NOESY Correlations of $\mathbf{6}$

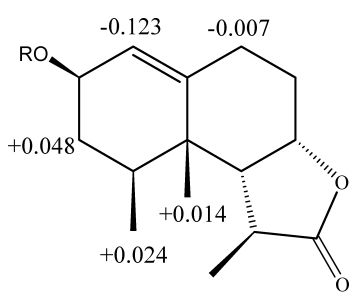

10a: $\mathrm{R}=(S)$-MTPA 10b: $\mathrm{R}=(R)$-MTPA

Fig. 5. ${ }^{1} \mathrm{H}-\mathrm{NMR}$ Chemical Shift Differences $\Delta \delta\left(\delta_{S}-\delta_{R}\right)$ in ppm for the MTPA Esters of $\mathbf{1 0}$ 
acetyl chlorides, respectively. The determination of the chemical shift differences $\left(\delta_{S}-\delta_{R}\right)$ for the protons neighboring $\mathrm{C}-2$ led to the assignment of the $R$ configuration at C-2 in 10 (Fig. 5). Thus, the absolute configuration of $\mathbf{1 0}$ has been determined.

The presence of both the C-12 methoxy epimers $(3,9)$ and the use of $\mathrm{MeOH}$ in the purification suggest that methoxycontaining compounds $\mathbf{1}, \mathbf{3}, \mathbf{4}$ and 9 might be artifacts. Treatment of 7 with $\mathrm{MeOH}$ and silica gel for $10 \mathrm{~d}$, however, led to the quantitative recovery of $\mathbf{7}$ without the formation of $\mathbf{1}$. Based on the shared biosynthetic pathway, compounds $1-9$ and $\mathbf{1 1}$ are assumed to have the same absolute configurations as $\mathbf{1 0}$ at $\mathrm{C}-4$ and $\mathrm{C}-5$, as these compounds were isolated from the same organism.

The cytotoxicity of compounds $\mathbf{1}-\mathbf{1 1}$ was tested against the proliferation of a limited panel of cancer cell lines, including MCF-7, WiDr, HEp 2, Daoy, CCRF-CEM, DLD-1, HL-60 and P388D1 carcinoma cells. The results showed that all of the compounds were not cytotoxic toward the above cancer cells ( $\mathrm{IC}_{50}$ 's $\left.>20 \mu \mathrm{g} / \mathrm{ml}\right)$.

\section{Experimental}

Melting points were determined using a Fisher-Johns melting point apparatus. Optical rotations were measured on a JASCO P-1020 polarimeter. Ultraviolet spectra were recorded on a JASCO V-650 spectrophotometer. IR spectra were recorded on a JASCO FT/IR-4100 infrared spectrophotometer. The NMR spectra were recorded on a Varian 400MR FT-NMR (or Varian Unity INOVA500 FT-NMR) instrument at $400 \mathrm{MHz}$ (or $500 \mathrm{MHz}$ ) for ${ }^{1} \mathrm{H}$ and $100 \mathrm{MHz}$ (or $125 \mathrm{MHz}$ ) for ${ }^{13} \mathrm{C}$ in $\mathrm{CDCl}_{3}$. Low resolution (LR)-MS and HR-MS were obtained by ESI on a Bruker APEX II mass spectrometer. Silica gel (Merck, 230 - 400 mesh) was used for column chromatography. Precoated silica gel plates (Merck, Kieselgel 60 F-254, $0.2 \mathrm{~mm}$ ) were used for analytical TLC. High-performance liquid chromatography was performed on a Hitachi L-7100 HPLC apparatus with a Merck Hibar Si-60 column $(250 \times 21 \mathrm{~mm}, 7 \mu \mathrm{m})$ and on a Hitachi L-2455 HPLC apparatus with a Supelco C18 column $(250 \times 21.2 \mathrm{~mm}, 5 \mu \mathrm{m})$.

Animal Material L. flava (specimen no. GI20070910-4) was collected by hand using scuba off the coast of Green Island, Taiwan, in September 2007 , at a depth of $10-15 \mathrm{~m}$, and stored in a freezer until extraction. A voucher sample was deposited at the Department of Marine Biotechnology and Resources, National Sun Yat-sen University.

Extraction and Isolation The frozen bodies of L. flava $(0.8 \mathrm{~kg}$, wet weight) were minced and exhaustively extracted with EtOAc $(11 \times 5)$. The EtOAc extract $(16.5 \mathrm{~g})$ was chromatographed over silica gel by column chromatography and eluted with EtOAc in $n$-hexane $(0-100 \%$, stepwise), then with acetone in EtOAc (50-100\%, stepwise) to yield 26 fractions. Fraction 13 , eluting with $n$-hexane-EtOAc $(20: 1)$, was further purified over silica gel using $n$-hexane-EtOAc $(3: 1)$ to afford six subfractions (A1-A6). Subfraction A3 was separated by reverse-phase HPLC using $\mathrm{MeOH}-\mathrm{H}_{2} \mathrm{O}(2.4: 1)$ to afford $4(2.2 \mathrm{mg})$. Fraction 14 , eluting with $n$-hexane-EtOAc $(10: 1)$, was further purified over silica gel using $n$-hexane-EtOAc $(2: 1)$ to afford eight subfractions (B1-B11). Subfraction B9 was separated by reverse-phase HPLC using $\mathrm{MeOH}-\mathrm{H}_{2} \mathrm{O}(3: 1)$ to afford $\mathbf{1}(6.5 \mathrm{mg}), 3(4.3 \mathrm{mg})$ and 9 $(12.8 \mathrm{mg})$. Fraction 15 , eluting with $n$-hexane-EtOAc $(10: 1)$, was further purified over silica gel using $\mathrm{CH}_{2} \mathrm{Cl}_{2}$-EtOAc $(10: 1)$ to afford eleven subfractions $(\mathrm{C} 1-\mathrm{C} 11)$. Subfraction $\mathrm{C} 3$ was separated by reverse-phase HPLC using $\mathrm{MeOH}-\mathrm{H}_{2} \mathrm{O}(1: 1.4)$ to afford 7 (16.5 mg) and $\mathbf{1 0}(12.5 \mathrm{mg})$. Subfraction $\mathrm{C} 4$ was separated by reverse-phase HPLC using $\mathrm{MeOH}-\mathrm{H}_{2} \mathrm{O}(1: 1.5)$ to afford $\mathbf{2}(1.7 \mathrm{mg}), \mathbf{8}(6.3 \mathrm{mg})$ and $\mathbf{1 1}(3.8 \mathrm{mg})$. Fraction 16 , eluting with $n$ hexane-EtOAc $(5: 1)$, and was further purified over silica gel using $\mathrm{CH}_{2} \mathrm{Cl}_{2}$-acetone $(9: 1)$ to afford seven subfractions (D1-D7). Subfraction D2 was separated by reverse-phase HPLC using $\mathrm{MeOH}-\mathrm{H}_{2} \mathrm{O}(1: 2.5)$ to afford $5(2.0 \mathrm{mg})$. Fraction 20, eluting with $n$-hexane-EtOAc $(1: 1)$, and was further purified over silica gel using $n$-hexane-acetone $(10: 3)$ to afford seven subfractions (E1-E7). Subfraction E5 was separated by reversephase HPLC using $\mathrm{MeOH}-\mathrm{H}_{2} \mathrm{O}(1: 2.1)$ to afford $6(1.3 \mathrm{mg})$.

Flavalin E (1): Colorless oil; $[\alpha]_{\mathrm{D}}^{23}-154\left(c=0.18, \mathrm{CHCl}_{3}\right)$; IR (neat) $v_{\max }$ 2970, 2938, 2884, 1654, 1456, and $1273 \mathrm{~cm}^{-1}$; UV (MeOH) $\lambda_{\max } 242$ $(\log \varepsilon=3.7) ;{ }^{13} \mathrm{C}$ - and ${ }^{1} \mathrm{H}$-NMR data, see Tables 1 and 2; ESI-MS $\mathrm{m} / z 287$ $[\mathrm{M}+\mathrm{Na}]^{+}$; HR-ESI-MS $m / z 287.1621[\mathrm{M}+\mathrm{Na}]^{+}$(Calcd for $\mathrm{C}_{16} \mathrm{H}_{24} \mathrm{O}_{3} \mathrm{Na}$,
287.1623).

Flavalin F (2): White solid; $\mathrm{mp} 124-126^{\circ} \mathrm{C} ;[\alpha]_{\mathrm{D}}^{23}-160(c=0.17$, $\mathrm{CHCl}_{3}$ ); IR (neat) $v_{\text {m }} 3356,2928,2865,2654,1739,1656,1460,1388$, and $1262 \mathrm{~cm}^{-1} ;{ }^{13} \mathrm{C}$ - and ${ }^{1} \mathrm{H}-\mathrm{NMR}$ data, see Tables 1 and 2; ESI-MS $\mathrm{m} / \mathrm{z} 275$ $[\mathrm{M}+\mathrm{Na}]^{+}$

Flavalin G (3): White solid; $\mathrm{mp} 128-130^{\circ} \mathrm{C} ;[\alpha]_{\mathrm{D}}^{23}-310 \quad(c=0.1$, $\mathrm{CHCl}_{3}$ ); IR (neat) $v_{\max } 2968,2920,2850,1709,1670,1456,1373$, and $1263 \mathrm{~cm}^{-1}$; UV (MeOH) $\lambda_{\max } 239(\log \varepsilon=4.4) ;{ }^{13} \mathrm{C}$ - and ${ }^{1} \mathrm{H}-\mathrm{NMR}$ data, see Tables 1 and 2; ESI-MS $m / z 287$ [M+Na] $^{+}$; HR-ESI-MS $m / z 287.1622$ $[\mathrm{M}+\mathrm{Na}]^{+}\left(\mathrm{Calcd}\right.$ for $\mathrm{C}_{16} \mathrm{H}_{24} \mathrm{O}_{3} \mathrm{Na}, 287.1623$ ).

Flavalin $\mathrm{H}(4)$ : Colorless oil; $[\alpha]^{23}-188\left(c=0.22, \mathrm{CHCl}_{3}\right)$; IR (neat) $v_{\max } 2931,2983,1717,1684,1452,1371$ and $1220 \mathrm{~cm}^{-1} ;{ }^{13} \mathrm{C}$ - and ${ }^{1} \mathrm{H}-\mathrm{NMR}$ data, see Tables 1 and 2; ESI-MS $m / z 331[\mathrm{M}+\mathrm{Na}]^{+}$; HR-ESI-MS $m / z$ $331.1881[\mathrm{M}+\mathrm{Na}]^{+}\left(\mathrm{Calcd}\right.$ for $\left.\mathrm{C}_{18} \mathrm{H}_{28} \mathrm{O}_{4} \mathrm{Na}, 331.1885\right)$.

Flavalin I (5): White solid; $\mathrm{mp} 213-215^{\circ} \mathrm{C} ;[\alpha]_{\mathrm{D}}^{23}-198\left(c=0.2, \mathrm{CHCl}_{3}\right)$; IR (neat) $v_{\max } 3333,2956,2916,2869,1716,1669,1383$, and $1261 \mathrm{~cm}^{-1}$; UV (MeOH) $\lambda_{\max } 245(\log \varepsilon=3.9) ;{ }^{13} \mathrm{C}$ - and ${ }^{1} \mathrm{H}-\mathrm{NMR}$ data, see Tables 1 and 2; ESI-MS $m / z 259$ [M+Na] ${ }^{+}$; HR-ESI-MS $m / z 259.1311[\mathrm{M}+\mathrm{Na}]^{+}(\mathrm{Calcd}$ for $\mathrm{C}_{14} \mathrm{H}_{20} \mathrm{O}_{3} \mathrm{Na}, 259.1310$ ).

Flavalin J (6): White solid; mp $160^{\circ} \mathrm{C} ;[\alpha]_{\mathrm{D}}^{23}-147\left(c=0.13, \mathrm{CHCl}_{3}\right)$; IR (neat) $v_{\max } 3393,2924,2857,1719,1657,1361$ and $1288 \mathrm{~cm}^{-1} ;{ }^{13} \mathrm{C}$ - and ${ }^{1} \mathrm{H}-$ NMR data, see Tables 1 and 2; ESI-MS $m / z 275[\mathrm{M}+\mathrm{Na}]^{+}$; HR-ESI-MS $m / z$ $275.1262[\mathrm{M}+\mathrm{Na}]^{+}$(Calcd for $\left.\mathrm{C}_{14} \mathrm{H}_{20} \mathrm{O}_{4} \mathrm{Na}, 275.1259\right)$.

Acetylation of 2 A solution of $\mathbf{2}(0.5 \mathrm{mg})$ in pyridine $(0.1 \mathrm{ml})$ was mixed with $\mathrm{Ac}_{2} \mathrm{O}(10 \mu \mathrm{l})$, and the mixture was stirred at room temperature for $12 \mathrm{~h}$. After evaporation of excess reagent, the residue was subjected to column chromatograph over $\mathrm{Si}$ gel using $n$-hexane-acetone $(3: 1)$ to give flavalin $\mathrm{H}$ acetate $(0.3 \mathrm{mg}, 53 \%)$. Selective ${ }^{1} \mathrm{H}-\mathrm{NMR}\left(\mathrm{CDCl}_{3}, 400 \mathrm{MHz}\right)$ data of flavalin $\mathrm{H}$ acetate: $\delta 5.44(1 \mathrm{H}, \mathrm{s}, \mathrm{H}-1), 5.32(1 \mathrm{H}, \mathrm{t}, J=8.4 \mathrm{~Hz}, \mathrm{H}-2), 2.44$ $(1 \mathrm{H}, \mathrm{m}, \mathrm{H}-9 \mathrm{a}), 2.44(1 \mathrm{H}, \mathrm{m}, \mathrm{H}-9 \mathrm{a}), 3.88(1 \mathrm{H}, \mathrm{t}, J=8.0 \mathrm{~Hz}, \mathrm{H}-12 \mathrm{a}), 3.48(1 \mathrm{H}$, t, $J=8.4 \mathrm{~Hz}, \mathrm{H}-12 \mathrm{~b}), 1.09(3 \mathrm{H}, \mathrm{d}, J=6.0 \mathrm{~Hz}, \mathrm{H}-13) 0.90(3 \mathrm{H}, \mathrm{d}, J=6.4 \mathrm{~Hz}$, $\mathrm{H}-14), 1.19$ (3H, s, H-15), $2.06(3 \mathrm{H}, \mathrm{s}, \mathrm{OAc})$. ESI-MS $m / z 317[\mathrm{M}+\mathrm{Na}]^{+}$; HR-ESI-MS $m / z 317.1728[\mathrm{M}+\mathrm{Na}]^{+}$(Calcd for $\mathrm{C}_{17} \mathrm{H}_{26} \mathrm{O}_{4} \mathrm{Na}, 317.1729$ ).

Preparation of $(S)$ - and $(R)$-MTPA Esters of 10 To a solution of $\mathbf{1 0}$ $(1.0 \mathrm{mg})$ in pyridine $(0.1 \mathrm{ml})$ was added $(R)$-MTPA chloride $(10 \mu \mathrm{l})$, and the mixture was allowed to stand for $12 \mathrm{~h}$ at room temperature. After the evaporation of the solvent, the residue was subjected to short silica gel column chromatography using $n$-hexane-acetone $(2: 1)$ to yield the $(S)$-MTPA ester, $10 \mathrm{a}(0.5 \mathrm{mg})$. The same procedure was applied to obtain the $(R)$-MTPA ester 10b $(0.5 \mathrm{mg})$ from the reaction of $(S)-(+)-\alpha$-methoxy- $\alpha$-(trifluoromethyl) phenylacetyl chloride with $\mathbf{1}$ in pyridine. Selective ${ }^{1} \mathrm{H}-\mathrm{NMR}\left(\mathrm{CDCl}_{3}\right.$, $400 \mathrm{MHz})$ data of 10a: $\delta 5.428(1 \mathrm{H}, \mathrm{s}, \mathrm{H}-1), 1.963(\mathrm{H}, \mathrm{m}, \mathrm{H}-3 \mathrm{a}), 2.138(1 \mathrm{H}$, m, H-9a), 0.966 (3H, d, $J=6.8 \mathrm{~Hz}, \mathrm{H}-14), 1.098(3 \mathrm{H}, \mathrm{s}, \mathrm{H}-15)$; selective ${ }^{1} \mathrm{H}-$ NMR $\left(\mathrm{CDCl}_{3}, 400 \mathrm{MHz}\right)$ data of 10b: $\delta: 5.551(1 \mathrm{H}, \mathrm{s}, \mathrm{H}-1), 1.915(\mathrm{H}, \mathrm{m}, \mathrm{H}-$ 3a), 2.145 (1H, m, H-9a), 0.942 (3H, d, $J=6.4 \mathrm{~Hz}, \mathrm{H}-14), 1.084$ (3H, s, H15).

Cytotoxicity Testing Cell lines were purchased from the American Type Culture Collection (ATCC). Cytotoxicity assays of compounds 1-11 were performed using the 3-(4,5-dimethylthiazol-2-yl)-2,5-diphenyltetrazolium bromide (MTT) colorimetric method. ${ }^{23,24)}$

Acknowledgments Financial support awarded to J.-H. Sheu was provided by Ministry of Education (97C031702) and National Science Council of Taiwan (NSC 98-2113-M-110-002 -MY3).

\section{References}

1) Sheu J.-H., Chao C.-H., Wang G.-H., Hung K.-C., Duh C.-Y., Chiang M. Y., Wu Y.-C., Wu C.-C., Tetrahedron Lett., 45, 6413-6416 (2004).

2) Tseng Y.-J., Wen Z.-H., Dai C.-F., Chiang M. Y., Sheu J.-H., Org. Lett., 11, 5030-5032 (2009)

3) Huang H.-C., Wen Z.-H., Chao C.-H., Ahmed A. F., Chiang M.Y., Kuo Y.-H., Hsu C.-H., Chen S.-P., Sheu J.-H., Tetrahedron Lett., 47, 87518755 (2006).

4) Lu Y., Huang C.-Y., Lin Y.-F., Wen Z.-H., Su J.-H., Kuo Y.-H., Chiang M. Y., Sheu J.-H., J. Nat. Prod., 71, 1754-1759 (2008).

5) Chao C.-H., Wen Z.-H., Wu Y.-C., Yeh H.-C., Sheu J.-H., J. Nat. Prod., 71, 1819-1824 (2008).

6) Su J.-H., Ahmed A. F., Sung P.-J., Chao C.-H., Kuo Y.-H., Sheu J.-H., J. Nat. Prod., 69, 1134-1139 (2006).

7) Chen B.-W., Chao C.-H., Su J.-H., Wen Z.-H., Sung P.-J., Sheu J.-H., Org. Biomol. Chem., 8, 2363-2366 (2010).

8) Ahmed A. F., Shiue R.-T., Wang G.-H., Dai C.-F., Kuo Y.-H., Sheu J.-H., Tetrahedron, 59, 7337-7344 (2003).

9) Ahmed A. F., Hsieh Y.-T., Wen Z.-H., Wu Y.-C., Sheu J.-H., J. Nat. 
Prod., 69, 1275-1279 (2006)

10) Chao C.-H., Wen Z.-H., Su J.-H., Chen I.-M., Huang H.-C., Dai C.-F., Sheu J.-H., Steroids, 73, 1353-1358 (2008).

11) Chao C.-H., Wen Z.-H., Chen I.-M., Su J.-H., Huang H.-C., Chiang M. Y., Sheu J.-H., Tetrahedron, 64, 3554-3560 (2008).

12) Wen Z.-H., Chao C.-H., Wu M.-H., Sheu J.-H., Eur. J. Med. Chem., 45, 5998-6004 (2010).

13) Bishara A., Yeffet D., Sisso M., Shmul G., Schleyer M., Benayahu Y., Rudi A., Kashman Y., J. Nat. Prod., 71, 375-380 (2008).

14) El-Gamal A. A. H., Chiu E.-P., Li C.-H., Cheng S.-Y., Dai C.-F., Duh C.-Y., J. Nat. Prod., 68, 1749-1753 (2005).

15) Yao G., Vidor N. B., Foss A. P., Chang L.-C., J. Nat. Prod., 70, 901905 (2007)

16) Jean Y.-H., Chen W.-F., Duh C.-Y., Huang S.-Y., Hsu C.-H., Lin C.-S., Sung C.-S., Chen I.-M.,Wen Z.-H., Eur. J. Pharmacol., 578, 323-331 (2008).

17) Lu Y., Li P.-J., Hung W.-Y., Su J.-H., Wen Z.-H., Hsu C.-H., Dai C.-F.,
Chiang M. Y., Sheu J.-H., J. Nat. Prod., 74, 169-174 (2011)

18) Bowden B. F., Coll J. C., Mitchell S. J., Nemorin L. E., Sternhell S., Tetrahedron Lett., 21, 3105-3108 (1980).

19) Tursch B., Colin M., Daloze D., Losman D., Karlsson R., Bull. Soc. Chim. Belg., 84, 81-82 (1975).

20) Duh C.-Y., El-Gamal A. A. H., Song P.-Y., Wang S.-K., Dai C.-F., J. Nat. Prod., 67, 1650-1653 (2004).

21) Daloze D., Breakman J. C. Georget P. Tursch B., Bull. Soc. Chim. Belg., 86, 47-54 (1977).

22) Ohtani I., Kusumi T., Kashman Y., Kakisawa H., J. Am. Chem. Soc., 113, 4092-4096 (1991).

23) Alley M. C., Scudiero D. A., Monks A., Hursey M. L., Czerwinski M. J., Fine D. L., Abbott B. J., Mayo J. G., Shoemaker R. H., Boyd M. R. Cancer Res., 48, 589-601 (1988).

24) Scudiero D. A., Shoemaker R. H., Paull K. D., Monks A., Tierney S., Nofziger T. H., Currens M. J., Seniff D., Boyd M. R., Cancer Res., 48, 4827 - 4833 (1988) 